\title{
An Assessment of the Impact of Information Technology on Marketing and Advertising
}

\author{
Zohre Hosseini \\ School of Management \\ Multimedia University \\ Malaysia
}

\author{
Sara Mohammadi \\ Faculty of Management and Economics \\ Shahid Bahonar University of Kerman \\ Iran
}

\author{
Hoda Safari \\ School of Management \\ Multimedia University \\ Malaysia
}

\begin{abstract}
The present study aimed to evaluate the impact of Technology on Marketing and Advertising by using structural equations modeling. To do this, 200 marketing and information technology (IT) experts participated in the study. They answered questionnaires regarding IT, marketing mix and advertising. For data analysis, structural equations modeling using SMARTPLS were used. The results showed that the effect of IT on marketing mix and advertising was positive and significant. The effect of marketing mix on advertising was positive and significant. The indirect effect of IT on advertising via marketing mix was therefore positive and significant. Totally, the results emphasized the effect of technology on marketing mix and advertising.
\end{abstract}

Keywords-technology; mass media; marketing; advertising

\section{INTRODUCTION}

Technology is defined as a combination of information equipment, techniques and processes needed to convert the data to output [1]. Main technology components like software, hardware, mind mapping software and support network, interact with each other [2]. Adopting appropriate technology does not mean the application of the advanced technology, but rather of the most appropriate which is consistent with a country's development objectives and available resources. Transfer of technology could be the most useful or useless of transactions and the effective use of transferred technology depends on the recipient country's efforts to adapt [3]. New technologies have a profound impact on structure and production. In recent decades, different systems and management tools have been provided to improve the structures, goals, and strategies [2]. The forms of "market uncertainty" and "uncertainty in technology" are two properties proposed for technology. Technological uncertainty refers to doubt about technology achievement and capability to respond to customer needs [4]. Hence it is necessary to examine industries and areas changed by technology in order to enhance the chances of success of technology. One of these areas is marketing. Marketing is one crucial factor for economy and society. As long as the gap between the producer and the consumer is slight and manufacturer is familiar enough with customers' needs and interests, there is no need for distribution and marketing agents. Moreover, when production is limited, factors like production planning, distribution strategy, marketing system completion etc. are of no concern for the manufacturers. However, in the case of mass production or when manufacturers target global markets and plan to distribute their products in a global scale, a wider range of marketing activities are required to deliver the product to the consumer. In the changing market conditions, it is expected for the existing marketing processes to face transformations and similarly, it is the market condition causing the success of a marketing plan. Thus, identifying and analyzing environmental factors such as the impact of new technologies in this field is of great importance.

The advertisement phenomenon was first performed through face-to-face verbal messages in the streets. Later, books became the most important means of disseminating information and advertisement while religious propaganda was conducted in mosques and minarets, churches, temples, schools and books. Progress of science, industry, and modern technology led to new ways of advertising with new equipments and tools [5]. In fact, advertising as a marketing technique plays a considerable role in the transfer of information (about products, services and business) to the consumer. Over time, advertising methods have changed due to the coming of new technology. The internet and mobile technology were presented as new advertising media. Mobile technology is able to create new markets, change organization competitive vision, create new opportunities and change the status of communication and market structures. Considering the above, the question emerges. What are the changes in the marketing and advertising industry imposed by the entrance of new technology?

\section{LITERATURE REVIEW}

With the arrival of communication technologies, the design of marketing mixture has more or less been altered. Basic marketing elements have been fundamentally transformed and continue to do so.

\section{A. Product Mix}

Product packaging and the presenting of product information in the internet reduces the need for physical testing and leads to saving time and money [7]. In e-commerce, acquisition of the customer's likes and designing products according to customer's opinion is facilitated [8]. 


\section{B. Price Mix}

Customers' quick access to competitors and their capability to quick compare prices, increased price competition between suppliers [10]. Also, when it comes to virtual stores design, the lack of opening cost consequently reduces product cost and thus the selling price [8].

\section{Distribution Mix}

For most buyers, the most important advantage of new technologies like internet is the ease of accessibility of the purchase place. Using new technology, home is a place to buy products [8]. In addition, via the internet one manufacturer can remove the distribution networks and get connected to the final customer. A customer can gather information, negotiate with vendors, order products and pay via the internet. These distribution network duties are now in the responsibility of the customer [9].

\section{Advertisement Mix}

Advances of propagation tools have changed data transfer from its most basic form of verbal messages and face to face interaction to e-mail or real time messages. New methods of advertising and marketing use the latest developments in technology to send advertising messages. New technologies have affected advertising in several domains.

\section{E. Advertisement Instruments}

TV used to be an effective mass media in presenting adds. Messages, letters, brochures and e-magazines accessible through the internet are the most recent advertisement instruments in the modern era.

\section{F. Advertisement Content}

Although, information essentially could function as an ad, it must be mentioned that in ads the content of information intends to affect audiences' attitudes and values. This impact occurs in two ways. As information presentation in the form of specific ads that could introduce new values in the society and create some desire towards the new values while making existing values insignificant. On the other hand, ads reflect the current society values along with individuals' ideas and desires. For years advertising has been involved more in transferring social values and attitudes and less in the notification of basic information about goods and services [10].

\section{G. Effectiveness of Advertising}

One of the most critical features of the internet is its reciprocal nature. When reviewing content of the web, customers can make a mutual relationship and determine how much and what kind of information they require [11]. Changing the communication patterns from in-person to group to group and group to individual are two other ad properties. Due to new technologies like internet the ad effectiveness and cost are affected. Through changing the communication models, efficiency of the ads will considerably increase [11].

\section{RESEARCH METHODOLOGY}

The study method is descriptive (non-experimental) and correlation of structural equations was done by the least partial squares method and the relationship between variables in the causal model [12]. Present study applies the partial least squares due to the benefits compared to covariance-based approach.

\section{A. Participants}

The participants are marketing and IT experts in Iran. 220 questionnaires are distributed by purposeful sampling method, of which 207 questionnaires were answered, 7 questionnaires were excluded from the analysis and finally, 200 questionnaires entered the analysis.

\section{B. Data Collection Measure}

To measure IT capability, the questionnaire presented in [6] was used. This questionnaire consists of 16 items. 8 relational items, 3 technical capability items and 5 managerial capability items. To measure marketing mix, a researcher-built questionnaire consisting of 14 questions was used. 4 items regarded product, 3 items regarded price, 4 items regarded distribution and 3 items propaganda. Another researcher built questionnaire was applied regarding advertisement. This questionnaire consists of 9 items. 3 items regarded content, 3 items tools and 3 items the effectiveness. All questions were answered on a five-item Likert scale of strongly disagree (1) to strongly agree (5).

\section{RESULTS}

\section{A. Measures Validity and Reliability}

The measurement test includes the evaluation of reliability (internal consistency) and validity (discriminant validity) of study constructs. To evaluate the reliability of constructs, authors in [13] proposed three criteria: Reliability of each of the items, composite reliability of each of the constructs and the average variance extracted. Regarding the reliability of each of items, the factor loading is 0.6 and above and in confirmatory factor analysis, it shows the suitability (Figures 1, $2,3)$. Also, the factor loading of items should be significant at the level 0.01 [14]. To calculate t-statistics to determine the significance of factor loading, boot strap (with 500 subsamples) is applied. To evaluate the composite reliability of each of constructs, Dillon-Goldstein's $\left(\rho_{c}\right)$ is applied. The acceptable values of $\rho_{c}$ should be 0.7 or higher. The third criterion of reliability is the average variance extracted [13], which is recommended to be 0.50 or above [15]. Tables I and II show factor loading, $\rho_{\mathrm{c}}$ and AVE of study variables. These values show suitable reliability of constructs. To evaluate validity or divergent validity, author in [15] recommended that items of a construct should have the highest factor loading on the construct. Authors in [14] proposed that the factor loading of each item on the construct should be at least 0.1 higher than the factor loading of the item on other constructs. Another criterion indicates that AVE square of a construct should be higher than its correlation with other constructs. This shows that the correlation of the construct with its indicators is higher 
than its correlation with other constructs. Table III shows the cross load of items on the study constructs. As shown in Table III, all dimensions have the highest factor loading on their construct, the least distance between the relevant factor loading is higher than 0.1 and the constructs have good validity. Table IV shows the results of correlation and second criterion of validity, square AVE.

TABLE I. FACTOR LOADING, COMPOSITE RELIABILITY AND AVE OF SECOND ORDER FACTOR ANALYSIS OF IT AND ADVERTISING

\begin{tabular}{|c|c|c|c|c|c|c|c|c|c|c|c|}
\hline Item & $\begin{array}{l}\text { Factor } \\
\text { loading }\end{array}$ & Item & $\begin{array}{l}\text { Factor } \\
\text { loading }\end{array}$ & Item & $\begin{array}{l}\text { Factor } \\
\text { loading }\end{array}$ & Item & $\begin{array}{l}\text { Factor } \\
\text { loading }\end{array}$ & Item & $\begin{array}{l}\text { Factor } \\
\text { loading }\end{array}$ & Item & $\begin{array}{l}\text { Factor } \\
\text { loading }\end{array}$ \\
\hline Managerial 1 & 0.66 & $\begin{array}{c}\text { Technical } \\
1\end{array}$ & 0.84 & Relational 1 & 0.65 & Content1 & 0.81 & Tool 1 & 0.83 & Effect1 & 0.73 \\
\hline Managerial 2 & 0.75 & $\begin{array}{c}\text { Technical } \\
2\end{array}$ & 0.87 & Relational 2 & 0.65 & Content 2 & 0.86 & Tool 2 & 0.72 & Effect2 & 0.86 \\
\hline Managerial 3 & 0.67 & $\begin{array}{c}\text { Technical } \\
3\end{array}$ & 0.89 & Relational 3 & 0.69 & Content 3 & 0.79 & Tool 3 & 0.76 & Effect3 & 0.86 \\
\hline Managerial 4 & 0.81 & & & Relational 4 & 0.70 & & & & & & \\
\hline Managerial 5 & 0.74 & & & Relational 5 & 0.72 & & & & & & \\
\hline & & & & Relational 6 & 0.78 & & & & & & \\
\hline & & & & Relational 7 & 0.76 & & & & & & \\
\hline & & & & Relational 8 & 0.67 & & & & & & \\
\hline $\begin{array}{l}\text { Cronbach's } \\
\text { alpha }\end{array}$ & 0.77 & & 0.83 & & 0.85 & & 0.75 & & 0.76 & & 0.75 \\
\hline$\rho_{\mathrm{c}}$ & 0.85 & & 0.90 & & 0.89 & & 0.86 & & 0.82 & & 0.86 \\
\hline AVE & 0.53 & & 0.75 & & 0.50 & & 0.67 & & 0.60 & & 0.67 \\
\hline
\end{tabular}

Note: All factor loading is significant at the level 0.01 and above

TABLE II. FACTOR LOADING, COMPOSITE RELIABILITY AND AVE OF SECOND ORDER FACTOR ANALYSIS OF MARKETING MIX

\begin{tabular}{|c|c|c|c|c|c|c|c|}
\hline Item & $\begin{array}{c}\text { Factor } \\
\text { loading }\end{array}$ & Item & $\begin{array}{c}\text { Factor } \\
\text { loading }\end{array}$ & Item & $\begin{array}{c}\text { Factor } \\
\text { loading }\end{array}$ & Item & $\begin{array}{c}\text { Factor } \\
\text { loading }\end{array}$ \\
\hline Product1 & 0.88 & Price 1 & 0.91 & Distribution 1 & 0.91 & Propaganda 1 & 0.85 \\
\hline Product2 & 0.89 & Price 2 & 0.93 & Distribution 2 & 0.90 & Propaganda 1 & 0.89 \\
\hline Product3 & 0.84 & Price3 & 0.90 & Distribution 3 & 0.85 & Propaganda 1 & 0.82 \\
\hline Product4 & 0.90 & & & Distribution 4 & 0.88 & & 0.82 \\
\hline Cronbach's alpha & 0.90 & & 0.90 & & 0.91 & & 0.89 \\
\hline$\rho_{\mathrm{c}}$ & 0.93 & & 0.94 & & 0.93 & & 0.73 \\
\hline AVE & 0.77 & & 0.83 & & 0.78 & & 0.00 \\
\hline
\end{tabular}

Note: All factor loading is significant at the level 0.01 and above

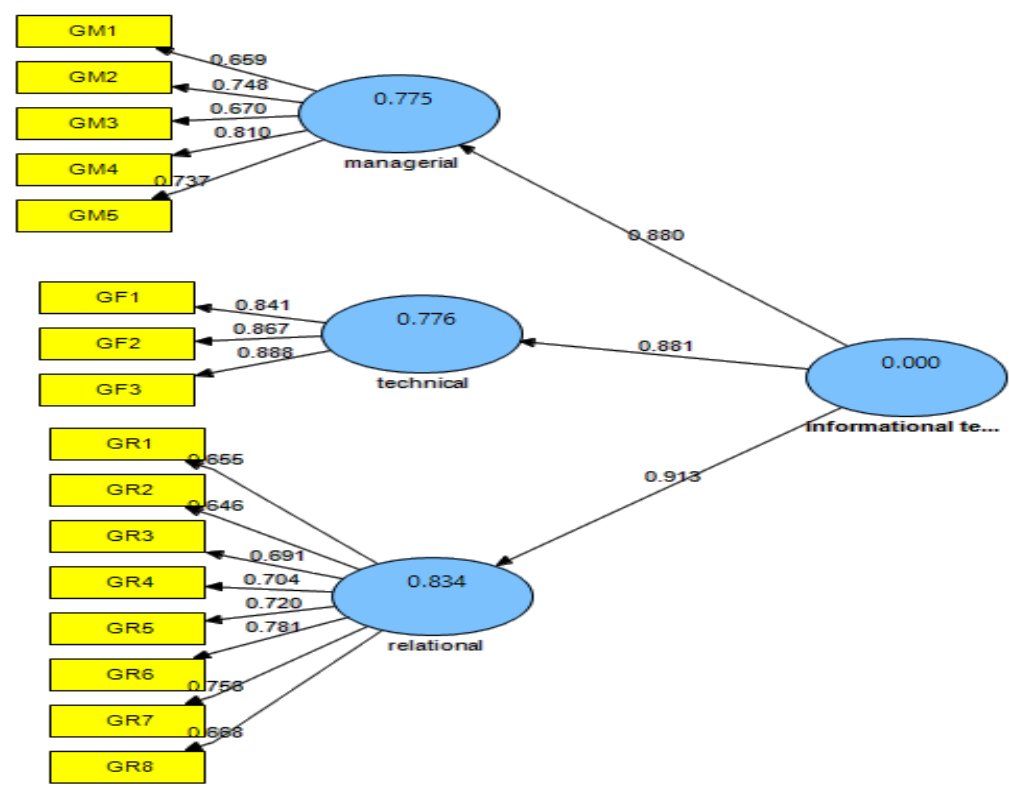

Fig. 1. The second order of factor analysis of IT 


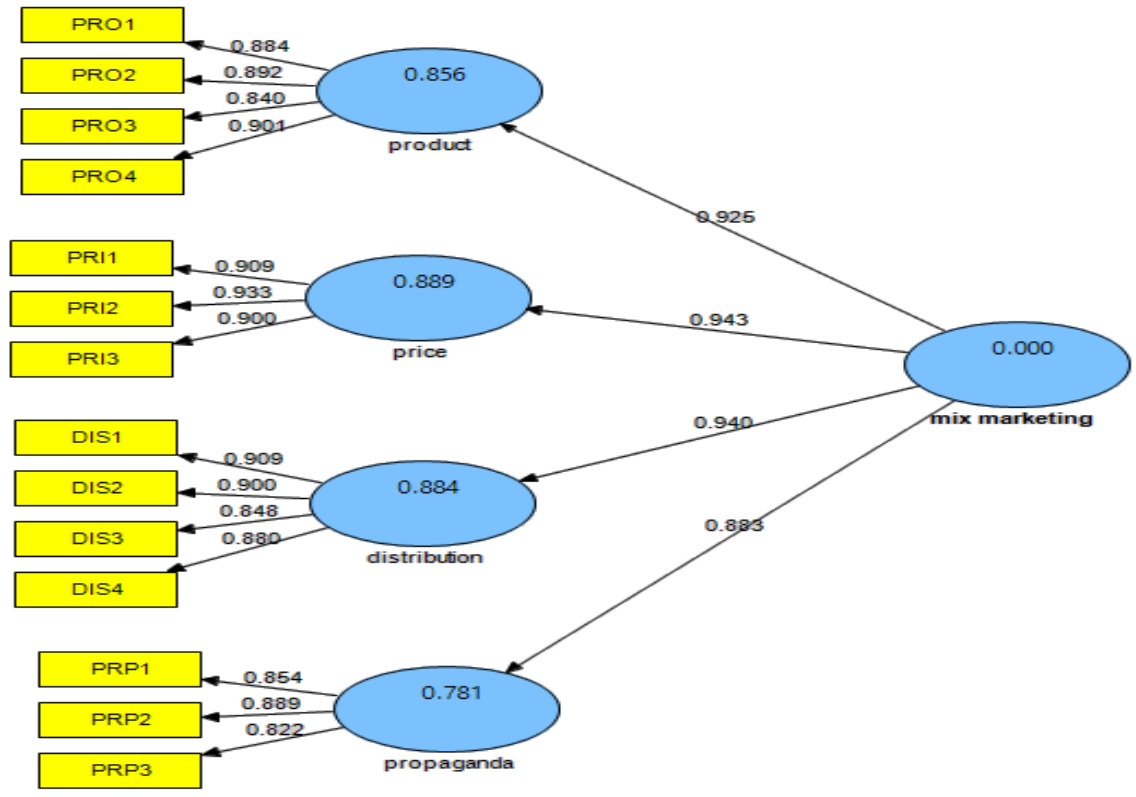

Fig. 2. The second order of factor analysis of marketing mix

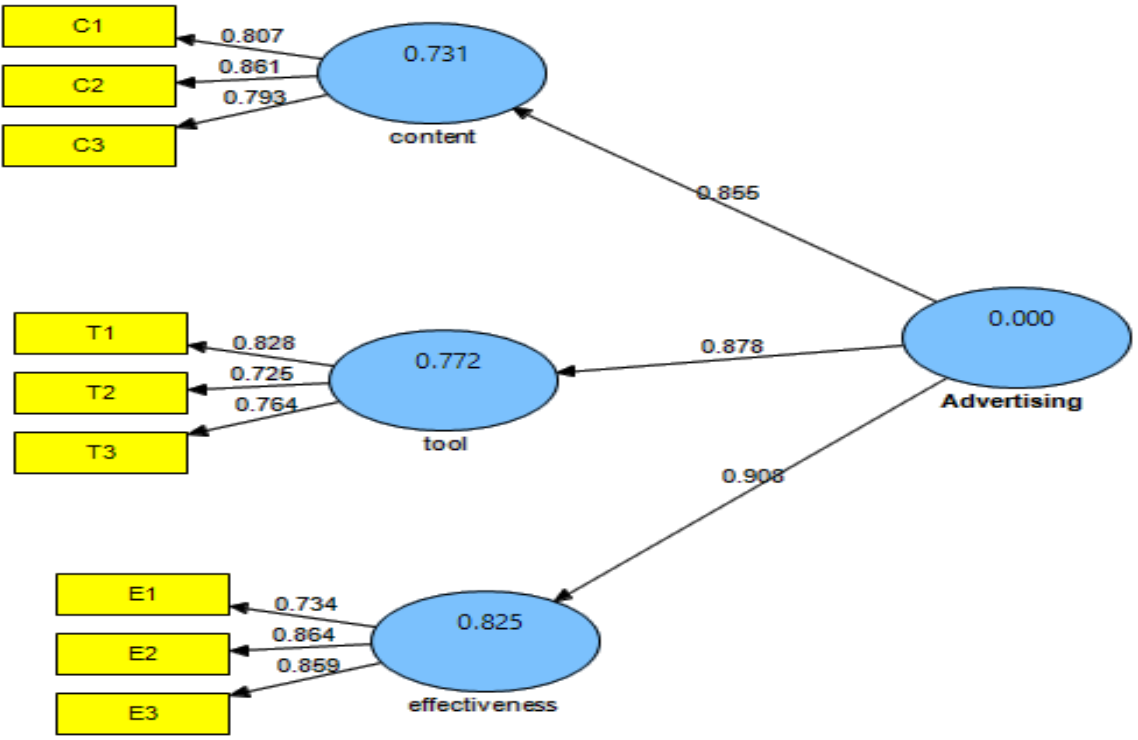

Fig. 3. The second order of factor analysis of advertising

TABLE III. CROSS FACTOR LOADING

\begin{tabular}{|c|c|c|c|c|}
\hline & $\begin{array}{c}\text { Informational } \\
\text { Technology }\end{array}$ & Mix Marketing & Advertising & \multirow{2}{*}{ AVE } \\
\cline { 1 - 4 } managerial & 0.88 & 0.42 & 0.47 & \multirow{2}{*}{0.79} \\
\hline relational & 0.88 & 0.56 & 0.55 & \multirow{2}{*}{0.85} \\
\hline technical & 0.91 & 0.50 & 0.57 & \\
\hline distribution & 0.51 & 0.93 & 0.52 & \multirow{2}{*}{0.77} \\
\hline price & 0.55 & 0.95 & 0.55 & \\
\hline product & 0.51 & 0.92 & 0.43 & 0.86 \\
\hline propaganda & 0.49 & 0.89 & 0.90 & \\
\hline content & 0.54 & 0.50 & 0.88 & \\
\hline effectiveness & 0.52 & 0.53 & &
\end{tabular}


TABLE IV. CORRELATION MATRIX AND SQUARE AVE OF STUDY VARIABLES

\begin{tabular}{|c|c|c|c|}
\hline & Informational technology & Mix marketing & Advertising \\
\hline Informational technology & 0.89 & - & - \\
\hline Mix marketing & 0.56 & 0.92 & - \\
\hline Advertising & 0.60 & 0.56 & 0.88 \\
\hline
\end{tabular}

As shown in Table IV, the square AVE of all study variables is higher than their correlation with other variables. Thus, second criterion of divergent validity of study variables is established. In addition, values below the diameter of correlation matrix are reported to evaluate the relationship between the variables. As shown, the correlation coefficient between variables is positive and significant.

\section{B. Structural Equations Modeling Test}

To predict advertising, the conceptual model via structural equation modeling is evaluated and based on the study hypotheses and the partial least squares method is used to estimate the model. Also, boot strap method (with 300 subsamples) is used to calculate the t-values to determine the significance of path coefficients. Figure 4 shows the tested model of the relationship between study variables. As shown, the effect of IT on marketing mix and advertising is positive and significant. The effect of marketing mix on advertising is positive and significant. Table $\mathrm{V}$ shows the estimation of path coefficients and the variance of study variables. The values inside the parentheses are $t$ coefficients.

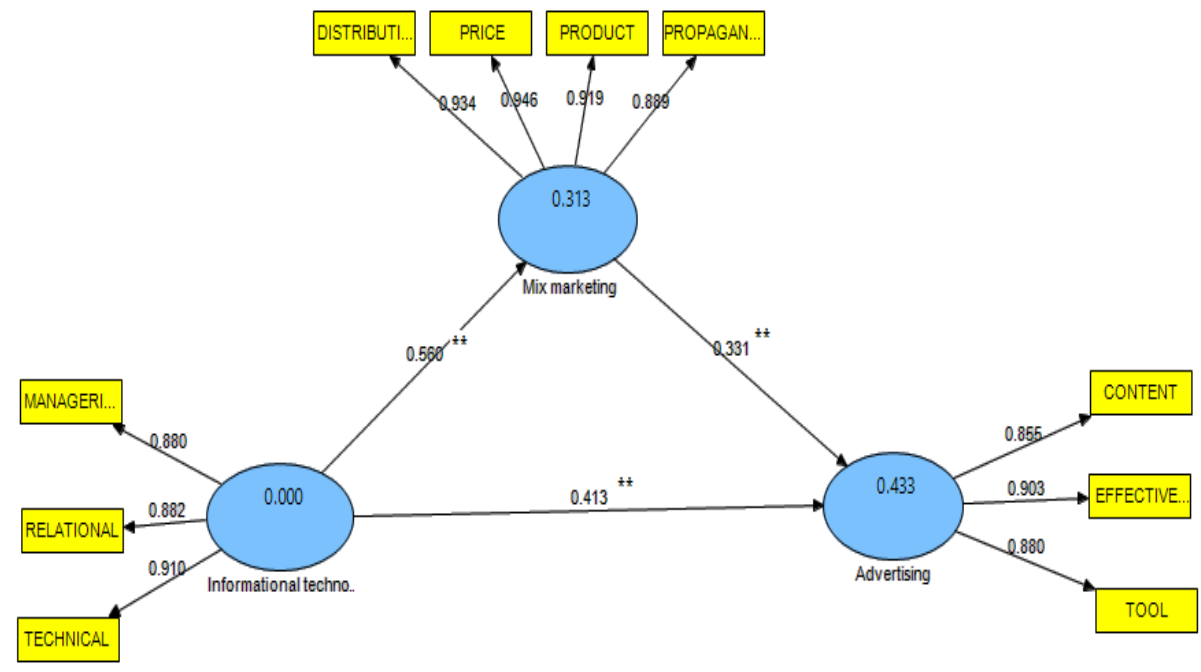

Fig. 4. Figure 4- The tested model of study

TABLE V. PATH COEFFICIENTS AND VARIANCE

\begin{tabular}{|c|c|c|}
\hline Variables & Path coefficients & Explained variance \\
\hline $\begin{array}{c}\text { On advertising from } \\
\text { Marketing mix } \\
\text { IT }\end{array}$ & $\begin{array}{l}0.33^{* *}(4.19) \\
0.41^{* *}(5.39)\end{array}$ & $43 \%$ \\
\hline On marketing mix from IT & $0.56^{* *}(8.55)$ & $31 \%$ \\
\hline The indirect effect of IT on advertising via marketing mix & $0.18^{* *}(3.76)$ & - \\
\hline
\end{tabular}

${ }^{*} \mathrm{p}<0.05,{ }^{* *} \mathrm{p}<0.01$

In addition to the indices of Table VI, total GOF (Goodness Of Fit) index of PLS model is used to evaluate the reliability or quality of PLS model as general. This index evaluates the total model prediction and whether the tested model is successful in the prediction of endogenous latent variables or not [16]. The present study has achieved GOF index 0.55 and the value of fit indicates good fit of the tested model. The present study aimed to evaluate the effect of IT on marketing and advertising by structural equations. The results showed that the proposed model has good fit with the study data and can explain $43 \%$ variance of advertising and $31 \%$ variance of marketing mix. Results showed that technology had positive and significant effect on marketing mix and advertising. We can say that the adoption of new technologies, the promotion of IT projects, the increase in key commercial technology use, the support in assignment of required resources to implement IT strategy, the 
consideration of IT training for employees, lead to the improvement of marketing mix and advertising. Results showed that marketing mix had positive and significant impact on advertising. We can say that if an organization decides to outperform the rivals, it should have suitable marketing strategies for success. Marketing mix provides a set of controllable marketing tools to respond the target market, includes all the tasks a company performs to affect the demand and leads to the advertising improvement.

TABLE VI. CV-COMMUNALITY AND CV-REDUNDANCY OF VARIABLES

\begin{tabular}{|c|c|c|}
\hline Study variables & $\begin{array}{c}\mathbf{Q}_{\mathbf{2}}(\mathbf{C V}- \\
\text { Redundancy) }\end{array}$ & $\begin{array}{c}\text { CV- } \\
\text { Communality }\end{array}$ \\
\hline Informational technology & - & 0.794 \\
\hline Mix marketing & 0.266 & 0.851 \\
\hline Advertising & 0.249 & 0.774 \\
\hline
\end{tabular}

\section{CONCLUSION}

Recent media technological advances have led to great changes in the contemporary world and new concepts like information technology, explosion of information and information community have been included in world languages. Within less than three decades, many outstanding transformations have occurred in the field of mass media. These transformations have also maximized the capacity of data transfer in terms either of information volume or transfer speeds. Main concern nowadays is not the lack of information, but rather the way to find strategies to manage and regulate a large bulk of information. All social, political and economic institutions are bound to take big steps and try to adjust with the rapid pace of technological advances. Development of communicative technologies in form of satellites, computers, cable TV, video conferences and computer networks have enabled people to access information more rapidly. Therefore, it is important to investigate the impact of technology on different parts of the market and marketing. Present research findings indicate that the new technology and its entrance into the marketing area have affected different aspects of marketing mix. According to marketing experts, advertising mix is the first part affected by the use of new technologies. The major role of advertising is to introduce a broad range of goods to the public and thus to reinforce the market economy. Accordingly the impact of this part of technology as the results and fitness of different aspects of marketing mix show, have influenced other aspects of marketing mix like product, price and distribution. Moreover, the results indicate that advertising and its components are affected by the new technologies. The advertising instruments according to the marketing experts have received the highest rate of effect.

\section{REFERENCES}

[1] M. Chatterji, Technology transfer in developing countries, St. Martin's Press, 1990

[2] M. Mahmoudzadeh, Managing the future with future technology, Iran Institute, 2001
[3] M. Larsson, A. Wall, C Norstrom, I. Crnkovic, "Technology transfer: why some succeed and some don't", 2006 international workshop on Software technology transfer in software engineering, pp. 23-28, 2006

[4] R. D. Stacey, Strategic thinking and change management: international ideas on organizational dynamism, translated by Mostafa Jafari, Rasa publication, 2010

[5] T. A. Ismail, J. H. Ahmad, "Public relations vs advertising", Jurnal Komunikasi, Malaysian Journal of Communication, Vol. 31, No. 2, pp. 117-130, 2015

[6] Gary Garrison, Robin L Wakefield, Sanghyun Kim, The effects of IT capabilities and delivery model on cloud computing success and firm performance for cloud supported processes and operations, International Journal of Information Management, Vol. 35, No. 4, pp. 377-393, 2015

[7] M. De Kare-Silver, E-shock 2000: the electronic shopping revolution: strategies for retailers and manufacturers, Springer, 1999

[8] H. Rahman, L. Han, Customer satisfaction in E-Commerce, A case study of China and Bangladesh, Msc Thesis, University West, 2001

[9] P. Timmers, Electronic commerce: strategies and models for business to business trading, John willey \& sond Ltd, 2000

[10] M. Hirt, P. Willmott, "Strategic principles for competing in the digital age", McKinsey Quarterly, Vol. 5, No. 1, 2014

[11] D. L. Hoffman, T. P. Novak, "Marketing in Hypermedia computerMediated environments: conceptual foundations", Journal of marketing, Vol. 60, No. 3, pp.50-68, 1996

[12] W. W. Chin, B. L. Marcolin, P. R. Newsted, "A partial least squares latent variable modelling approach for measuring interaction effects: Results from a Monte Carlo simulation study and an electronic-mail emotion/adoption study", Information Systems Research, Vol. 14, No. 2, pp.189-217, 2003

[13] C. Fornell, D. F. Larcker, "Evaluating structural equations models with unobservable variables and measurement error", Journal of Marketing Research, Vol. 18, No. 1, pp. 39-50, 1981

[14] D. Gefen, D. Straub, "A practical guide to factorial validity using PLSGraph: Tutorial and annotated example", Communications of the Association for Information Systems, Vol. 16, No. 5, pp. 91-109, 2005

[15] W. W. Chin, "Commentary: Issues and opinion on structural equation modeling", MIS Quarterly, Vol. 22, No. 1, pp. vii-xvi, 1998

[16] M. Seyed Abasszadeh, J. Amani, H. K. Azar, G. Pashouy, "An Introduction of Structural Equations Modeling by PLS Method and its Application in Behavioral Sciences", Oroumieh University Publication, Vol. 2, No. 1, pp. 126-139, 2012 